\title{
Effective Removal of Nitrate, Nitrite, Ammonia and Iron from Contaminated Ground Water using Bio-Sand Method and Sponge Layer Filtration Method
}

\author{
Puspa Lal Homagai* and Sujan Poudel \\ ${ }^{1}$ Amrit Campus, Tribhuvan University, Thamel, Kathmandu, Nepal \\ Email:homagaipl@gmail.com
}

\begin{abstract}
A study was undertaken to compare the removal efficiency of Nitrate, Nitrite, Ammonia and Iron from ground water by using Bio-Sand and Sponge layer Filtration process. Samples were collected from ground water sources of different locations of Kathmandu, Bhaktapur and Lalitpur districts. The concentration of these elements was found over the WHO guideline for drinking water. The pH values of all water samples were found to lie within Nepal Standard 6.5 to 8.5. The concentration of ammonia varies from place to place although most of the well water in these districts was found above the WHO guideline $1.5 \mathrm{mg} / \mathrm{L}$. Nitrate, nitrite and iron are also varied place to place. The removal percentage of Nitrate, Nitrite, Ammonia and Iron was found 82.949, 84.28176.342 and 89.336 percentage in Bio-Sand Filtration Process in an average and was found 86.067, 86.020, 80.768 and 93.138 percentage in Sponge Layer Filtration Process.
\end{abstract}

Keywords: Bio-Sand Filtration, Sponge layer Filtration, Water contamination, Toxic ions

\section{Introduction}

Water contaminations by toxic chemicals and biological agents are being serious problems now days ${ }^{1}$. The levels of nitrate ${ }^{2}$, nitrite ${ }^{3}$, ammonia ${ }^{4}$, iron ${ }^{5}$ and other toxic chemicals present in water helps to monitor the standard of drinking water. High levels of nitrites are toxic to humans as well as animals, especially infants. It can enter the body as nitrate and be converted into nitrite, which disrupts the oxygen delivering ability of hemoglobin in the blood stream. Nitrite was shown to react with nitrosatable compounds in the human stomach to form N-nitroso compounds ${ }^{6}$. Blue baby syndrome (methemoglobinemia) is being serious problems in infants caused by excess nitrate ${ }^{7}$. Beside the nitrate and nitrite, excess ammonia also plays vital role in muscle weakness, fatigue, kidney disfunctioning or even damage. Inhalation of lower concentrations of ammonia can cause coughing with nose and throat irritation which can cause bronchiolar and alveolar edema, and airway destruction resulting in respiratory distress or even failure . $^{8}$ The presence of ammonia at higher than geogenic levels is an important indicator of faecal pollution. Such Nitrates, Nitrites and Ammonia in the ground water are generally from fertilizer runoff, leaky cesspools, sewage treatment plants, manure runoff and unmanaged septic.

\footnotetext{
${ }^{*}$ Corresponding author
} 
Iron contamination in drinking water has been recorded from last decade and found to cause Anemia which is common all over the world among many demographics affecting more than $40 \%$ of the world's population and disproportionately affecting nearly half of all women, adolescent girls, and children ${ }^{9,10}$. Iron exist in both the oxidation state $\mathrm{Fe}(\mathrm{I})$ and $\mathrm{Fe}(\mathrm{II})$ state and has great role in human body functioning by the transport of the oxygen throughout the body ${ }^{11}$. Iron is not hazardous to health as it required for body functioning up to a certain limit, but it is considered a secondary or aesthetic contaminant ${ }^{12}$. Water disagreeable metallic taste is given by dissolved ferrous iron whereas an inky black appearance and unacceptable taste is given when it combines with tea, coffee and other beverages ${ }^{13}$. When vegetables were cooked in water containing excessive iron then it turns dark and look unappealing.

Bio-sand filter is an innovative version of the slow sand filter specifically designed for water purification that uses sand, gravels and concretes about the size of an office water cooler with some simple engineering to purify water contaminated with biologics and chemicals ${ }^{14}$. Generally, Bio-sand system is made up of concrete filled with layers of gravel and sand that encourage the growth of naturally present microbes in water, just like in the ground in nature. These microbes develop into biolayer or biofilm, which destroys disease-causing pathogenic microbes to create clean drinking water. The sand also causes pathogenic microbes to become trapped, adsorbed or sucked that help to die from lack of food or oxygen ${ }^{15}$. This is the way how Bio-sand filtration system worked for purification of dirty water contaminated with microbes.

Like this, for purification of water different filter system such as activated alumina water filter ${ }^{16}$, filter with activated carbon, ceramic filter, reverse osmosis filter, ultraviolet water purifier, water distillation, water filter pitcher, faucet water filter, showerhead filter, countertop water filter, under sink water filter, whole house water filter system has been used widely entire the world. Similarly low cost sponge is also used widely for the adsorption of different metals like arsenic, iron, lead, cadmium, nitrate, nitrite, ammonia etc. In this research Sponge layer filtration was used for the comparable study with widely used Bio-sand filtration for the purification of water. The main objective of this research work is to compare the Bio-sand water purification system and Sponge layer filtration system for the removal of Nitrate, Nitrite, Ammonia and Iron. This research will be boon for the water purification system with low cost that can be prepared by using locally available materials.

\section{Experimental Methods}

\section{Installation of Bio-Sand Reactor}

Bio-sand reactor consisting sand, gravels and concretes about size of an office water cooler was instilled manually. It was made by using locally available buckets. The buckets were arranged in column. Contaminated water was supplied at the rate of $140 \mathrm{~mL}$ per minute from the top of column. It was allowed inside the system and drained out from the bottom of the filter system. Water prevents sand from drying and it also keeps moisture in fine sand during the formation of a biofilm layer and prevents the layer of biofilm from damage. Diffusion plate made up of fiber plastic was adjusted just above water surface to maintain water flow rate. Water is received through orifice hole placed on the lateral pipe. Locally available river sand was selectively sieved, using a set of sieves for sand analysis. The portion passing through $0.25 \mathrm{~mm}$ sieve and retained on $0.150 \mathrm{~mm}$ was used in this study as filter medium. Filter 


\section{J. Nepal Chem. Soc., Vol. 39, 2018}

medium have an effective size of $0.22-0.25 \mathrm{~mm}$ filled into the reactor with depth of $40 \mathrm{~mm}$ on the top and coarse sand of $0.50 \mathrm{~mm}$ size and $20 \mathrm{~cm}$ in the middle of media. Finally, in the last bottom layers of under drain have gravel of $12-14 \mathrm{~mm}$ size of $20 \mathrm{~cm}$. Sand and gravels were washed with clean water several times to eliminate pollutant present in filtration media and it was dried in an oven for 24 hours at the temperature of $110^{\circ} \mathrm{C}$ for sterilization, after that media were put into reactor sequentially. Filter media were sieved and washed to remove clay particles, organic contents and other materials in accordance to meet standard procedures. Finally, filter water was collected and nitrate, nitrite, ammonia and iron were measured and tally with standard value for drinking water prescribed by WHO.

\section{Instillation of Sponge Layer Filter System}

The slices of sponge filter were collected from the local market. To compare the results obtained from Sponge layer filter method with Bio-sand method, flow rate of water was fixed of $140 \mathrm{ml}$ per minute from the inlet. The sponge slice of one meter was lay down up to 30 meter in horizontal position for an adsorption process. Sponge slices were overlaps one after another to make layer. This whole system was covered with hard plastic bag to remove the air contamination and to protect the system from external agents. Then water was allowed on the surface of the sponge for the adsorption of nitrate, nitrite, ammonia and iron. Concentrations of these elements before and after the filtration were recorded. Finally, filtered water was collected and nitrate, nitrite, ammonia and iron were measured and tally with standard value for drinking water prescribed by WHO.

\section{Water Sources}

Pure drinking water has been still problem for peoples living in Kathmandu, Bhaktapur and Lalitpur district of Nepal. Water sources like tap, well, pump and water reserve tank were used for daily activities such as washing clothes, bathing and for drinking water within these districts. For this experiment water samples were collected from different locality of Kathmandu, Bhaktapur and Lalitpur district and allows to filtration system.

\section{Chemicals and Reagents}

\section{Reagents for Nitrate and Nitrite}

Nitrate test was done by using $1 \mathrm{~N}$ Hydrochloric acid prepared by adding $110 \mathrm{ml}$ of distilled water with $10 \mathrm{ml}$ of Hydrochloric acid. For the test of nitrite, coloring reagent was prepared by adding phosphoric acid of $5 \mathrm{ml}$ with sulfanilamide of $0.5 \mathrm{~g}$ and mixed with $0.05 \mathrm{gm} \mathrm{N}$-(1-napthyl ethylene diamine dihydrochloride) and rinsed in volumetric flask of $50 \mathrm{ml}$ up to the mark.

\section{Reagents for Ammonia}

Solution A was prepared by taking $200 \mathrm{ml}$ distilled water and $2.5 \mathrm{gm}$ of phenol and $0.0125 \mathrm{gm}$ of sodium nitroprusside in volumetric flask of $250 \mathrm{ml}$ and it was rinsed up to the mark by adding distilled water. Similarly, Solution B was prepared by adding $6.25 \mathrm{ml}$ of sodium hypochlorite and $3.75 \mathrm{gm} \mathrm{NaOH}$ in $100 \mathrm{ml}$ of distilled water and rinsed up to the mark of $250 \mathrm{ml}$ of standard volumetric flask. 


\section{Reagents for Iron}

Reagents for Iron was used as HCL, Hydroxylamine Solution, Ammonium acetate buffer solution, Phenanthroline solution of $0.2 \mathrm{~mL}, 0.1 \mathrm{~mL}, 1 \mathrm{~mL}$ and $0.4 \mathrm{~mL}$ respectively.

\section{Results and Discussion}

Nitrate, Nitrite, Ammonia and Iron in ground water has been regarded as serious problem in Nepal and also entire the world. All most all people entire the world consumed large amount of ground water for washing, bathing cooking, drinking, hydro electricity generation and irrigation purpose. According to the census record of 2068 BS, all most all 435,544 households' people of Kathmandu, 68,557 households people of Bhaktapur and 109,505 households people of Lalitpur District were depend upon ground water resources to conduct different activity in daily life. It has seen that most of the people of Kathmandu, Bhaktapur and Lalitpur district use Tap water or Piped water rather than Tube well water, Spout water, Rain water and River water. 3,223 households people of Kathmandu, 410 households people of Bhaktapur and 1,035 households people of Lalitpur have not started any of water sources for drinking water indicates, how much scarcity has been faced by Nepalese till now for pure drinking water. Rest of the remaining water supply rather than these are also found under the WHO standard for direct use of drinking water purpose.

Table 1: Households by source of drinking water

\begin{tabular}{|c|l|c|c|c|c|c|c|c|c|c|}
\hline S.N & \multirow{2}{*}{ District } & Total & \multicolumn{7}{|c|}{ Source of Drinking Water } \\
\cline { 4 - 11 } & & & $\begin{array}{l}\text { Tap / } \\
\text { piped }\end{array}$ & $\begin{array}{l}\text { Tube well / } \\
\text { and pump }\end{array}$ & $\begin{array}{c}\text { Covered } \\
\text { well }\end{array}$ & $\begin{array}{c}\text { Uncovered } \\
\text { well }\end{array}$ & $\begin{array}{l}\text { Spout } \\
\text { water }\end{array}$ & $\begin{array}{l}\text { River / } \\
\text { stream }\end{array}$ & Others & $\begin{array}{c}\text { Not } \\
\text { stated }\end{array}$ \\
\hline 1 & Kathmandu & 435,544 & 269,909 & 34,977 & 29,085 & 5,565 & 19,263 & 1,471 & 72,051 & 3,223 \\
\hline 2 & Bhaktapur & 68,557 & 53,438 & 2,607 & 4,775 & 1,862 & 3,342 & 42 & 2,081 & 410 \\
\hline 3 & Lalitpur & 109,505 & 75,073 & 1,050 & 10,691 & 2,004 & 4,718 & 243 & 14,691 & 1,035 \\
\hline
\end{tabular}

This data provides sufficient evidence for the use of ground water resources in Kathmandu, Bhaktapur and Lalitpur District. About 613,606 households of Kathmandu, Bhaktapur and Lalitpur District utilize ground water resources for day to day purposes. Contamination of this water brings hazardous effect for social stability, economic development and entire steps forward of the Nation. To overcome such problems faced by contaminated ground water, low cost water purification process should be increase rapidly. This research is oriented to remove chemical and microbial toxicity from impure and contaminated ground water resources. Bio-sand Filtration and Sponge layer filtration process were used to remove the contamination of drinking water sources in this research. The removal percentage is calculated by following relation.

$$
\text { Removal \% }=\frac{C_{i}-C_{e}}{C_{i}} \times 100 \%
$$

Where, $\boldsymbol{C}_{\boldsymbol{i}}$ and $\boldsymbol{C}_{\boldsymbol{e}}$ are initial and final concentration of respective ions. 


\section{J. Nepal Chem. Soc., Vol. 39, 2018}

Peoples of Kathmandu are resentment to keep their drinking water clean. Whether it's of streams, rivers, tube well, boring or tap water; peoples have taken great measures to maintain high quality drinking water for both human as well as animal consumption. Clean drinking water is precious resource and key to human survival. But contamination of water is being serious problem day by day. Water sample from different 14 locations of Balaju were collected and was found toxic to drink directly for drinking purpose. The following result of figure 1 and 2 was result found in sampling spot of Balaju location.

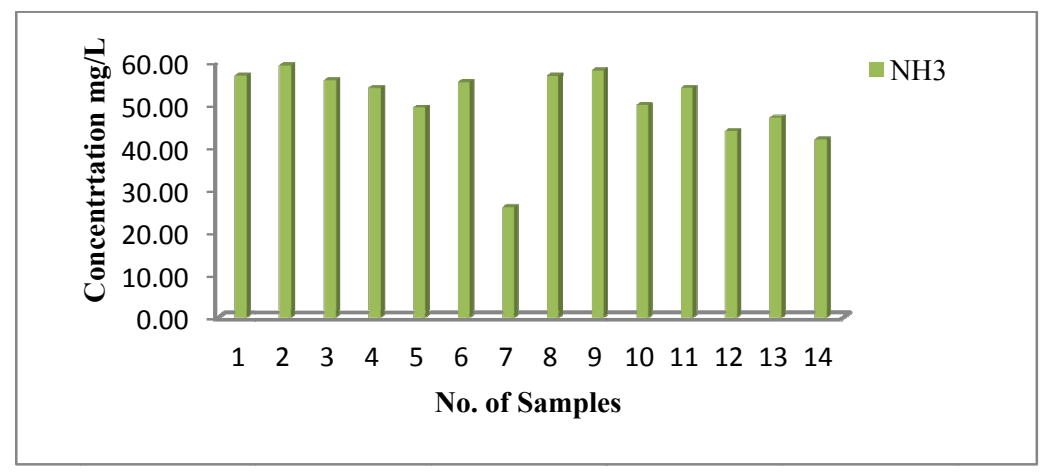

Figure 1 : Concentration profile of Ammonia of Kathmandu sampling point

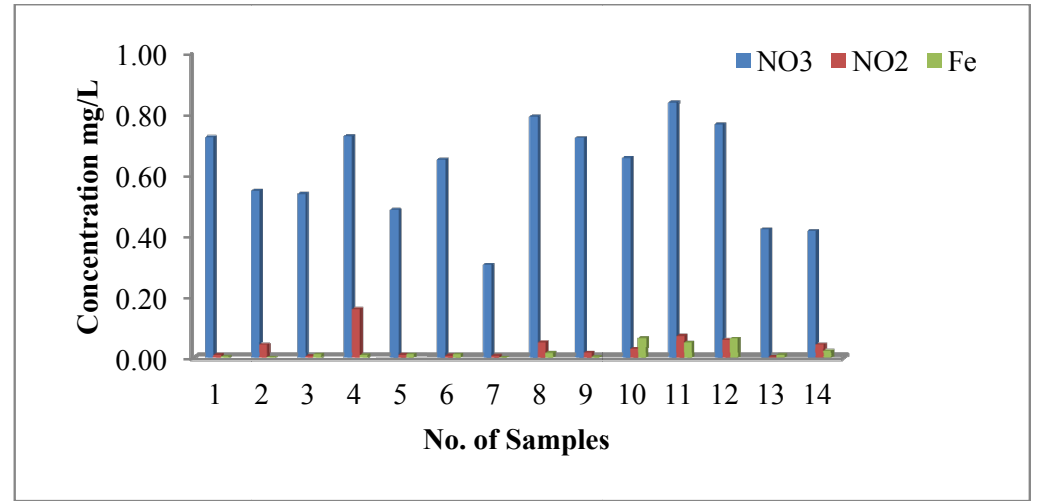

Figure 2 : Concentration profile of Nitrate, Nitrite and Iron of Kathmandu sampling point

All the 14 samples of figure 1 and 2 were collected from different location of Balaju of Kathmandu sampling point. The sample of 1, 2, 3, 4, 5, 6, 7, 8 and 9 were collected from tube well of Balaju area. It was collected from different houses tube well water of Balaju area. Samples 10, 11, 12, 13 and 14 were collected from tap water within this locality. The above figure 1 and 2 shows that water sampling site of Kathmandu contains nitrate nitrite, ammonia and iron. It was found that the concentration of ammonia was found in higher concentrations than nitrate, nitrite and iron. It has higher value than prescribed by WHO for drinking water. Balaju is an industrial area having more than 50 industries with in small area. These industries produce different organic and inorganic substances as by product which were sewage out through open drainage and unfortunately mixes with water sources leading the raise in concentration of ammonia, nitrate, nitrite and others toxic chemicals. It may be region behind the increase of ammonia in 
well water of Balaju. When man-made products such as gasoline, oil, road salts and chemicals get into the groundwater and cause it to become unsafe and unfit for human use. Mines, metal, aluminum, pipe, polymers, auto mechanical, bakery, noodle, dairy, herbal, paper, plastic, garment, silk, rubber and Battery likes industries are located in Balaju Industrial Area. Several industries within in small area of mid-city may give some effort on environmental problems which directly or indirectly affect the water contamination within this locality. Similarly, water sample were collected from different sources of Bhaktapur district. The figure 3 and 4 is obtained from the 14-sampling point of Bhaktapur district.

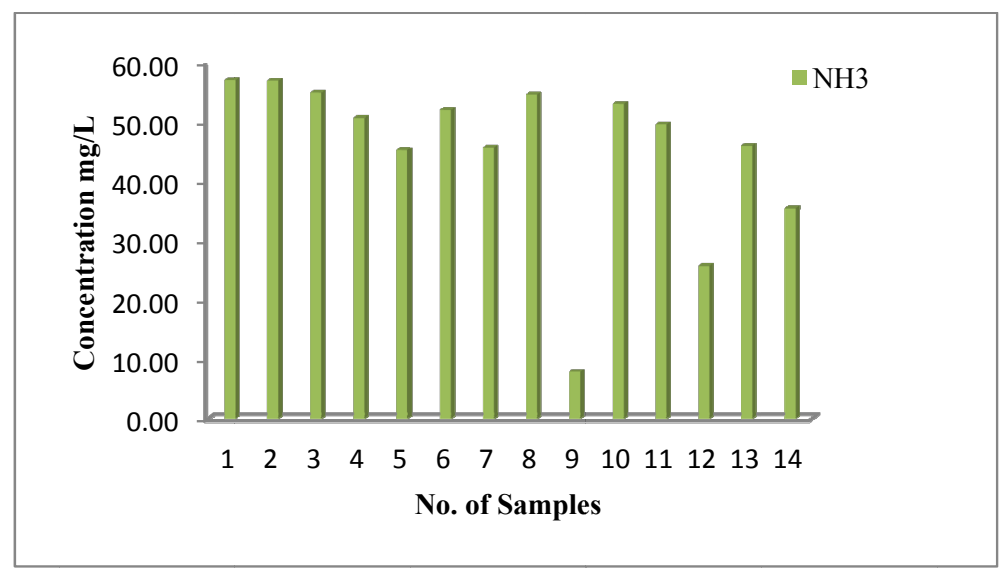

Figure 3 : Concentration profile of Ammonia of Bhaktapur sampling point

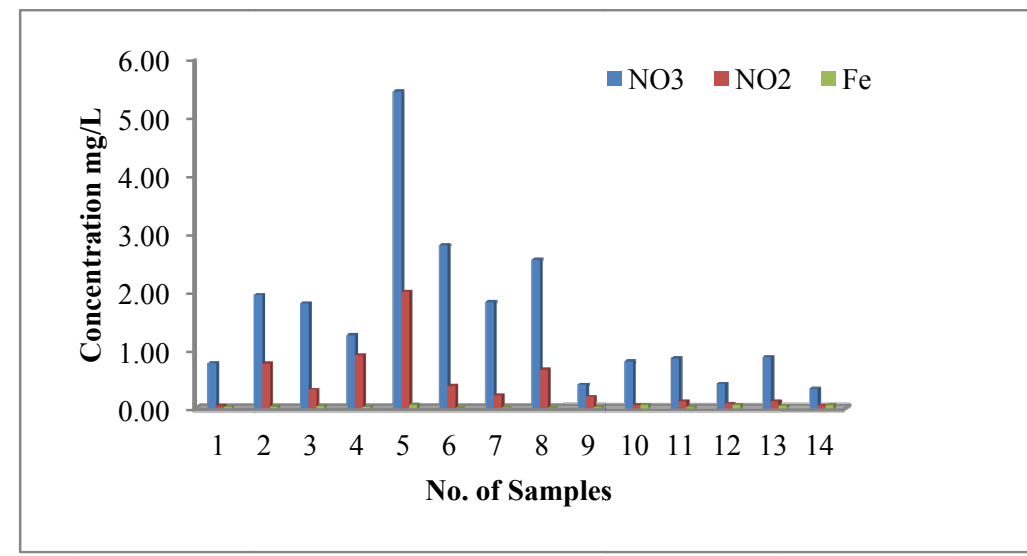

Figure 4 : Concentration profile of Nitrate, Nitrite and Iron of Bhaktapur sampling point

Like of Kathmandu location the water of Bhaktapur sampling also shows higher concentration of ammonia along with nitrate and nitrite. The ammonia concentration varies from $10 \mathrm{mg} /$ liter to around 60 $\mathrm{mg} / \mathrm{liter}$ which is too much high than WHO drinking water guideline $1.5 \mathrm{mg} / \mathrm{l}$. Similarly nitrate concentration also varies from $0.5 \mathrm{mg} / 1$ upto $5 \mathrm{mg} / \mathrm{l}$. It indicates that some of the well has lower concentration within the WHO guideline value and more are of out of WHO limit. The above figure 3 and 4 gives an idea about how much water contaminated in Bhaktapur district. The overused of fertilizer and 


\section{J. Nepal Chem. Soc., Vol. 39, 2018}

organic manure decomposition also push up in increasing concentration of ammonia. It may be one of the regions for increasing concentration of ammonia in this district. Local domestic industries, unmanaged sewage distribution and overpopulation also influences on environmental pollution along with ground water problems within this district. Similarly, water sample were collected from different 14 location of Jwagal of sample site of Lalitpur district. The sample 1, 2, 3, 4, 5, 6, 7, 8 and 9 were collected from tube well, well and ground water sources available in locality. This has excess amount of ammonia and nitrate. Sample 10,11, 12, 13 and 14 were collected from water supplies for tape water.

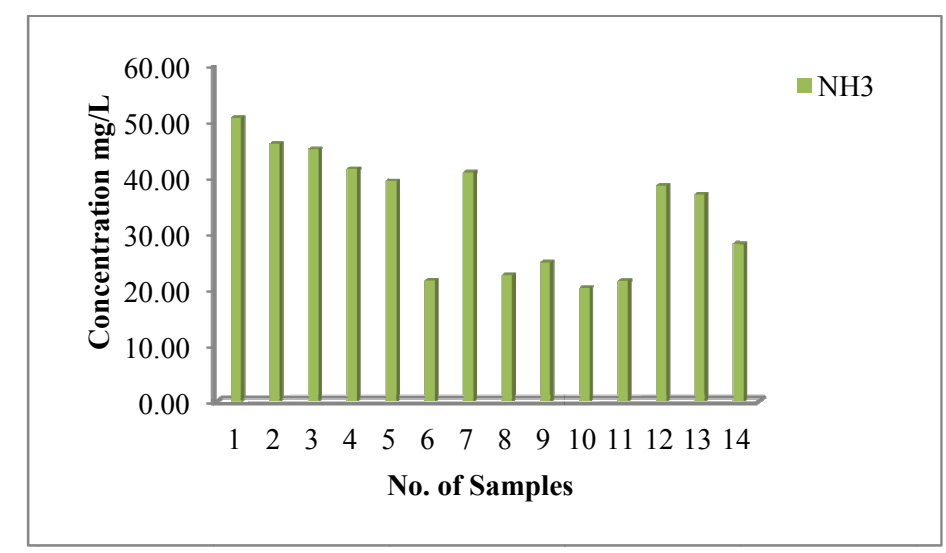

Figure 5 : Concentration profile of Ammonia of Lalitpur sampling point

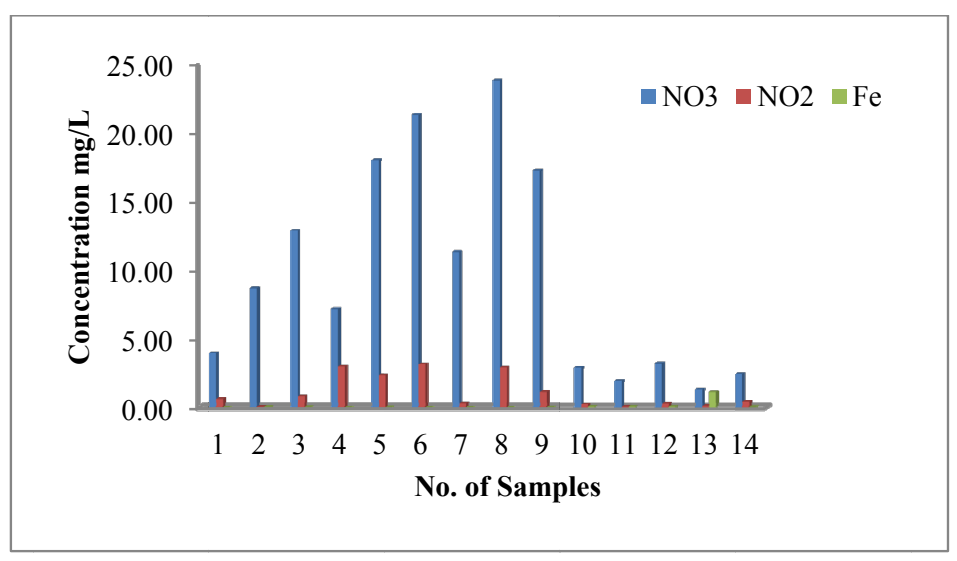

Figure 6 : Concentration profile of Nitrate, Nitrite and Iron of Lalitpur sampling point

The figure 5 and 6 shows that well water of Lalitpur also contaminated with excess ammonia along with nitrate and nitrite. The ammonia concentration varies from 20 to $50 \mathrm{mg} / \mathrm{L}$ and nitrate varies from 0.5 to around $25 \mathrm{mg} / \mathrm{L}$. It indicates high concentration of ammonia and nitrate. The consumption of such water without any purification causes several health effects. Most of the sampling places were contaminated by excess ammonia it may be by decomposition of organic matter nearer to the water sources. Prominent ammonia concentrations in groundwater are often associated with anthropogenic sources such as sewage effluent, leaking manure, and through landfill leach ate process. This excess of 
ammonia in ground water indicates how much environmental pollution is ongoing process. Due to of over population, industrialization has been increased and byproduct of such industrialization mixes with unmanaged sewage drain which directly grounded by water recharging process leading in rise the concentration of nitrate, nitrite, ammonia, iron and others toxic chemicals. Water is most crucial element for most of the living life in the Earth and being contaminated such element brings somber effects. Different methods have been developed to purify contaminated water. Peoples uses sediment filtration, ion exchange, activated carbon, ultra violet light, micro filter, reverse osmosis, ozonation, bottling process etc. to purify contaminated water. Water has significant role for functioning of human body. How much water should consume by body is depends upon weight of the body although most of the health authorities commonly recommended about two liters or half of a gallon pure drinking water crammed with minerals should consume per day for healthy life. This research aimed to minimize the contamination of such crucial water and focus on purification process. To achieve the aim water samples from different location were collected in reserve tank and allows to filtration system to observe amputation of water contamination. During the filtration of such contaminated water following result was achieved successfully.

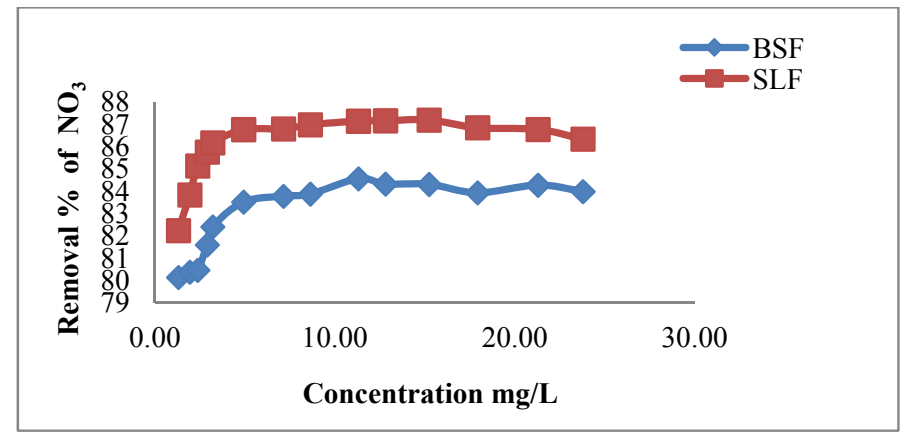

Figure 7: Concentration Profile of $\mathrm{NO}_{3}-\mathrm{N}$ using Bio-Sand Filtration and Sponge Layer Filtration

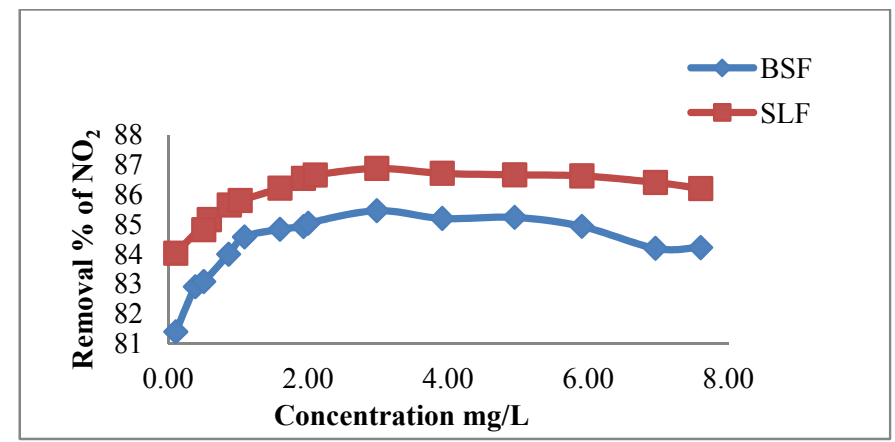

Figure 8: Concentration Profile of $\mathrm{NO}_{2}-\mathrm{N}$ using Bio-Sand Filtration and Sponge Layer Filtration 


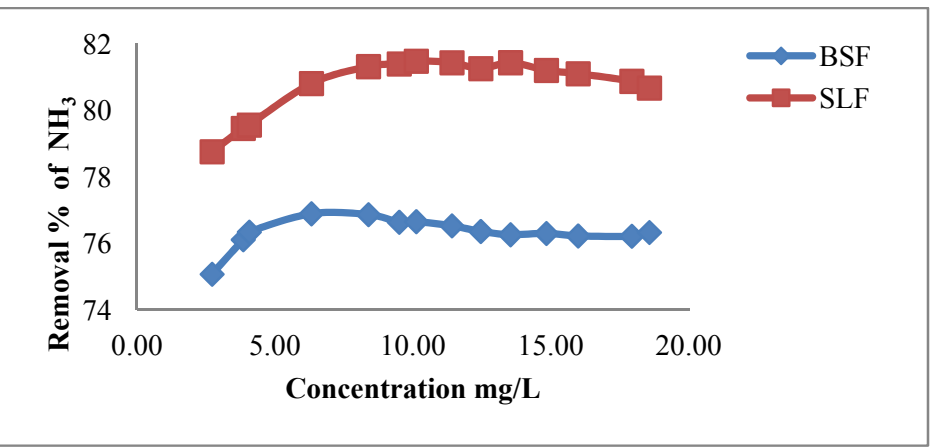

Figure 9: Concentration Profile of $\mathrm{NH}_{3}-\mathrm{N}$ using Bio-Sand Filtration and Sponge Layer Filtration

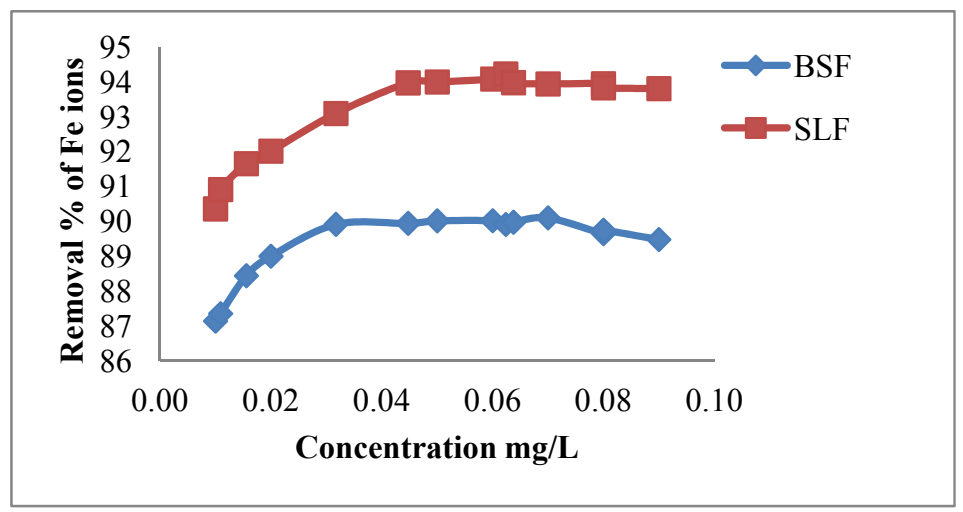

Figure 10: Concentration Profile of Fe ions using Bio-Sand Filtration and Sponge Layer Filtration

It was found that both Bio-sand filtration process and Sponge layer filtration gives effective result for the removal of Nitrate, Nitrite, Ammonia and Iron. Not only the chemical parameters it was found that the process also help to remove microbial contamination effectively. The following results were observed during the experiments.

Table 2: Microbial effectiveness of filtration process

\begin{tabular}{|c|c|c|c|c|c|c|}
\hline S.N & Filter System & Bacteria & Viruses & Protozoa & Helminthes & Turbidity \\
\hline 1 & BSF & Up to & $70-99 \%$ & $>99.9 \%$ & Up to $100 \%$ & $\begin{array}{c}95 \%<1 \\
\text { NTU }\end{array}$ \\
\hline 2 & SLF & Up to & $70-99 \%$ & $>99.9 \%$ & Up to $100 \%$ & $\begin{array}{c}99.5 \%<1 \\
\text { NTU }\end{array}$ \\
\hline
\end{tabular}

It signify that Bio-sand filter and Sponge layer filter can be used for any kind of water sources like well water, borehole water, pond water, river water, tap stand water, even in rain water. This makes it very convenient for people because they can use whichever water source is closest to home, make it safe to drink. In case of Bio-sand method, water must not be chlorinated though, or the chlorine will kill the biolayer. The water should not contain any dangerous chemicals, because the Bio-sand filter cannot 
remove most chemicals from water. It has found that contaminated water poured into the top of the Biosand filter at least once per day but not continuously. For the sponge layer also it has found that it must be wash and clean time to time. Otherwise it could not precede effective result. The water passed into the top of the filter slowly drips through the holes in the diffuser, and flows down through the sand and gravel. Treated water flows out of the outlet tube and filtration works is done by gravity. Pathogens and suspended solids are removed through biological and physical processes that take place in the sand. These processes include mechanical trapping, predation, adsorption, and natural death.

Government of Nepal has also focus of attention on drinking water standard. According to Environment Statistics of Nepal 2008, Government of Nepal, National Planning Commission Secretariat, Central Bureau of Statistics, Kathmandu, Nepal, the following standard is recommended.

Table 3: Government of Nepal and WHO guidelines for drinking Water quality

\begin{tabular}{|c|c|c|c|c|}
\hline S.N & Parameters & $\begin{array}{c}\text { Maximum Concentration } \\
\text { Limit Prescribed by Gov.of } \\
\text { Nepal }\end{array}$ & $\begin{array}{c}\text { Maximum } \\
\text { Concentration Limit } \\
\text { Prescribed by WHO }\end{array}$ & $\begin{array}{c}\text { Concentration in } \\
\text { Drinking Prescribed } \\
\text { by WHO }\end{array}$ \\
\hline 1 & Nitrate & $50 \mathrm{mg} / \mathrm{L}$ & $50 \mathrm{mg} / \mathrm{L}$ & $<0.1 \mathrm{mg} / \mathrm{L}$ \\
\hline 2 & Nitrite & $50 \mathrm{mg} / \mathrm{Ll}$ & $50 \mathrm{mg} / \mathrm{L}$ & $<0.1 \mathrm{mg} / \mathrm{L}$ \\
\hline 3 & Ammonia & $1.5 \mathrm{mg} / \mathrm{L}$ & $1.5 \mathrm{mg} / \mathrm{L}$ & $<0.02 \mathrm{mg} / \mathrm{L}$ \\
\hline 4 & Iron & $\begin{array}{l}0.3 \mathrm{mg} / \mathrm{L} \text { (figure in parenthesis } \\
\text { are upper range of Standard } \\
\text { recommended) }\end{array}$ & $0.3 \mathrm{mg} / \mathrm{L}$ & $<0.3 \mathrm{mg} / \mathrm{L}$ \\
\hline
\end{tabular}

Various researches have been already done for the purification of water using Bio-sand method and sponge filtration method. It is widely used in developing and under developing countries where is problem to used advance filtration and purification process because of low economic status. This research is oriented for those ultra-poor and vulnerable families who can easily use such filtration system for purification process. The above figure 7, 8, 9, 10 shows application of such filtration process in our daily life but it has also some drawbacks that it should be maintain regularly which is quite trouble for users. This Bio-sand filtration method and Sponge filtration method of water purification is being traditional method by the development of sophisticated technology although it has been still running in under develop countries. Recently several advance technologies have been developed which performs effective result than such process. This research was performed just to minimize the drinking water problems in under developing countries like Nepal. The figure 1, 2, 3, 4, 5 and 6 shows that there is contamination of excess ammonia in all the 14 samples spot of each Kathmandu, Bhaktapur and Lalitpur district of Nepal. The sample of Lalitpur district was shown the concentration of nitrate, nitrite and ammonia in quite higher concentration. Similarly, Bhaktapur drinking water sample has also problem for direct used of well water because of higher ammonia concentration. Excess of iron can be removed by the aeration process also. It has seen most of the houses use aeration process to overcome iron concentration but excess ammonia concentration has been removed from ground water. Unmanaged sewage distribution along with stool drain may play role in leakage of drinking water pipe supply leading water contamination. It was found that the pipes lines of drinking water and stool drain should be avoided or should manage scientifically to avoid unwanted leakage contamination of tap water with in these districts. Unmanaged 


\section{J. Nepal Chem. Soc., Vol. 39, 2018}

industries sewage, organic matter decomposition, overused of fertilizer also influences in increase of ammonia, nitrate, nitrite and other chemicals in well water. Over population entire the world increases the industrialization which affects the environmental problems entire the world. This earth is common for all people around the world and inter connected to each other so problems faced in one place may be by next places so the attention of entire world should focus on such common problems entire the world.

The $\mathrm{pH}$ values of all water samples were found to lie within Nepal Standard. Hardness of water was found in wide range of variation it may be by the concentration of Ammonia, Nitrate, Nitrite and other elements. A number of sources in these districts were found within Nepal standard limit only for nitrate and nitrite and people are using such water for washing and irrigation purpose. Unknowing people were facing several diseases by the consumption of harmful bacteria with the drinking water within these districts. The contamination of water with such elements and its compounds plays vital role for different diseases in the locality. Traditional water resources were found more contaminated than modern tap water. Utility of such compound for agricultural product as fertilizer will be solution form site effect of such compound. People can cultivate various kinds of plants which inhale such compounds and helps to control water contamination problems. Various research works had done previously to minimize the concentration of such compound in drinking water and some are still running. This research is the outcome of problems faced by such elements in drinking water. Such compounds can be removed from drinking water by the use of Bio sand filtration process and Sponge filtration process which can be uses in both urban and ruler areas. Sponge layer filtration will be effective in urban area whereas Bio sand filtration process will be effective in ruler areas. The percent removal was found well in all these compounds in both Bio-Sand Filtration process and Sponge Layer Filtration Process. The removal percentage of Nitrate, Nitrite, Ammonia and Iron was found 82.949, 84.281 76.342 and 89.336 percentage in Bio-Sand Filtration Process in an average and was found 86.067, 86.020, 80.768 and 93.138 percentage in Sponge Layer Filtration Process. It indicates that both systems were suitable for purification of water in developing countries like Nepal.

\section{Conclusions}

It has been concluded that both Bio-sand filtration and Sponge layer filtration system can be used in developing country. The effectiveness for both systems is of reasonable limit because of low cost and locally available materials are sufficient for the purification of water containing contamination of Nitrate, Nitrite, Ammonia and Iron which has adverse effect on human health as well as environmental aspect. It is concluded from the survey analysis result that it is essential to supply pure drinking water for people of rural and urban areas.

\section{Acknowledgements}

The authors are thankful to Head of Department of Chemistry, Amrit Campus, Tribhuvan University, Kathmandu, Nepal for providing the available research facilities to conduct this research work successfully. 


\section{References}

1. P.L., Homagai and S. Poudel, Journal of Nepal Chemical Society, 2017, 36, 27-34.

2. S.G. Zhu, Journal of the American College of Cardiology, 2011, 57(21), 2181-2189.

3. S.D. Gangolli, European Journal of Pharmacology, Environmental Toxicology and Pharmacology Section, 1994, 292, 1-38.

4. Summary review of health effects associated with ammonia, Washington, DC, US Environmental Protection Agency, 1989 (EPA/600/8-89/052F).

5. T.H. Bothwell et al. Iron metabolism in man. Oxford, Blackwell, 1979.

6. C. Chilvers, H. Inskip and C. Caygill., A survey of dietary nitrate in well-water users. International Journal of Epidemiology, 1984, 13, 324-331.

7. G. Walton, Survey of literature relating to infant methemoglobinemia due to nitrate contaminated water. American Journal of Public Health, 1951, 41, 986-996.

8. International Organization for Standardization, Water quality-determination of ammonium, Geneva, 1984, 1986.

9. E. McLean, M. Cogswell, I. Egli, D. Wojdyla and D, B. de Benoist, WHO Vitamin and Mineral Nutrition Information System, Public Health Nutr, 1993-2005, 12, 444-454.

10. Y. Balarajan, U. Ramakrishnan, E. Olazaltin, AH. Shankar and SV. Subramanian, Anemia in low-income and middle-income countries, 2011, 378, 2123-2135.

11. P.L. Homagai, K.N. Ghimire and K. Inoue, Separation Sci. Technol, 2011, 46, 1-10.

12. Requirements of vitamin A, iron, folate and vitamin $B_{12}$. Report of a Joint FAO/WHO Expert Consultation. Rome, Food and Agriculture Organization of the United Nations, FAO Food and Nutrition Series, No. 23, 1988.

13. National Food Agency of Denmark, Food monitoring in Denmark, Copenhagen, Publication No. 195, 1990.

14. L.C. Campos, M.J.F. Su, N.J.D. Graham, and S.R. Smith, Biomass development in slow sand filters. Water Research, 2002, 36 (18), 4543-4551.

15. G. Palmateer, D. Manz, A. Jurkovic, R. McInnis, S. Unger, K.K. Kwan and B.J. Dutka, Environmental Toxicology, 1999, 14, 217-225.

16. V.S. Chauhan, P.K. Dwivedi and L. Iyengar, J. Hazardous Materials, 2007, 139, 103-107. 